〔99】金属アルキルによる酢酸ビニルの重合

第 1 報 金属アルキルと酢酸ビニル系の赤外線吸収スペクトル

(1958 年 12 月 20 日受理)

滕 井 洌* ·江口保*

浮田純二*・松本昌一*

\begin{abstract}
要旨 トリエチルホウ素 $\left(\mathrm{B}\left(\mathrm{C}_{2} \mathrm{H}_{5}\right)_{3}\right)$ およびジメチルカドミウム $\left.\left(\mathrm{Cd} / \mathrm{CH}_{3}\right)_{2}\right)$ に対して, 酢酸ビニル (VAcがどのように挙動するかを, 赤外線吸収スペクトルによって観察した。 $\mathrm{B}\left(\mathrm{C}_{2} \mathrm{H}_{5}\right)_{3}$ の添加によってVAc の $\mathrm{C}=\mathrm{O}$ による $1774 \mathrm{~cm}^{-1}$ の特性吸収が分岐し，1754 $\mathrm{cm}^{-1}$ に新しい吸収が現われること，その吸収の吸光 度の比は両物質のモル比が 1:1 付近で最大となること,また $\mathrm{Cd}\left(\mathrm{CH}_{3}\right)_{2}$ の場合も同样の変化がみられるが, そ の傾向: $\mathrm{B}\left(\mathrm{C}_{2} \mathrm{H}_{5}\right)_{3}$ の場合と若干異なること、さらにポリ酢酸ビニル(PVAc)のエステル結合上も相互作用を 示すことが認められた。アルミニウム，严鉛のアルキル化合物も $\mathrm{Cd}\left(\mathrm{CH}_{3}\right)_{2}$ 同㥞 VAc および PVAcとも反 応することが認められた。
\end{abstract}

\section{1. 緒言}

金属アルキルによるビニル化合物の重合については, 古川ら ${ }^{1)}$ の金属化合物の触媒能全般にわたる体采的な研 究や芦刘 ${ }^{21}$ の研究をはじめ, 最近よく研究が行なわれて いる。著者らは種々の金属アルキルに対してVAc がど のように挙動するかを赤外線吸収スペクトルにより観察 した。本報告では $\mathrm{B}\left(\mathrm{C}_{2} \mathrm{H}_{5}\right)_{3}$ と $\mathrm{Cd}\left(\mathrm{CH}_{3}\right)_{2}$ につき比較検 討し、VAc が両者に対してかなり異なった挙動を示す ことを認めたので報告する。

\section{2. 実駼方法}

VAcの $5 \% \mathrm{n}$-へキサン溶夜(あるいは石油エーテル 溶液)に種々の割合で金属アルキルを添加して赤外線吸 収スペクトルの変化を観察した。溶液の調製は空素下で 行ない, 吸収スペクトルの測定は Perkin Elmer 112 型 (シングルビーム,ダブルパス)によった。プリズムは岩 塩であり,七ルは岩塩で厚さ $0.5 \mathrm{~mm}$, 機械的スリット幅

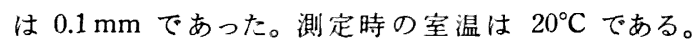
$\mathrm{B}\left(\mathrm{C}_{2} \mathrm{H}_{5}\right)_{3}$ および $\mathrm{Cd}\left(\mathrm{CH}_{3}\right)_{2}$ はそれぞれグリニャ一試薬 と三フッ化ホウ素および臭化カト゚ミゥムの反応から得た ものを使用した。

\section{3. 実験結果ならび考察}

\subsection{VAc-B $\left(\mathrm{C}_{2} \mathrm{H}_{5}\right)_{3}$ 系}

VAc の $5 \% \mathrm{n}$-ヘキサン溶液に等モル量の $\mathrm{B}\left(\mathrm{C}_{2} \mathrm{H}_{5}\right)_{3}$ を添加すると, VAc の $\mathrm{C}=\mathrm{O}$ の特性吸収を示す 1774 $\mathrm{cm}^{-1}$ の吸収に分岐を生じ，第 1 図に示すよ5に 1754 $\mathrm{cm}^{-1}$ に新しい吸収が出現する。 $\mathrm{B}\left(\mathrm{C}_{2} \mathrm{H}_{5}\right)_{3}$ の添加量を種 タ変えて実験した結果, 第2 図仙示すよ5にこの吸収の 吸光度の比はVAc: $\mathrm{B}\left(\mathrm{C}_{2} \mathrm{H}_{5}\right)_{3}=1: 1$ (モル比) 付近で最大

\footnotetext{
* 倉教レイヨン株式会社研究所(倉敖市酒津)
}

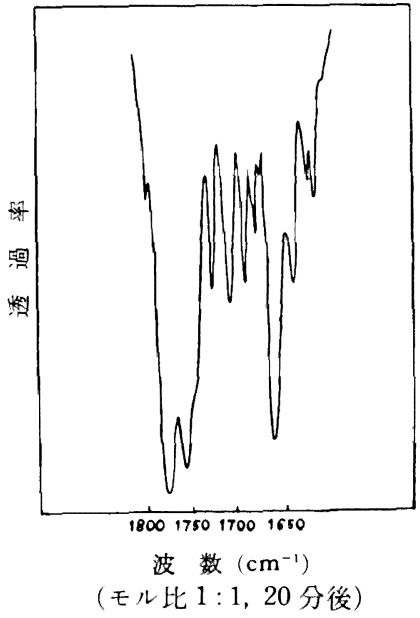

第 1 図 VAc のーキサン溶液に $\mathrm{B}\left(\mathrm{C}_{2} \mathrm{H}_{5}\right)_{3}$ を添加し たときの赤外線吸収スペクトル

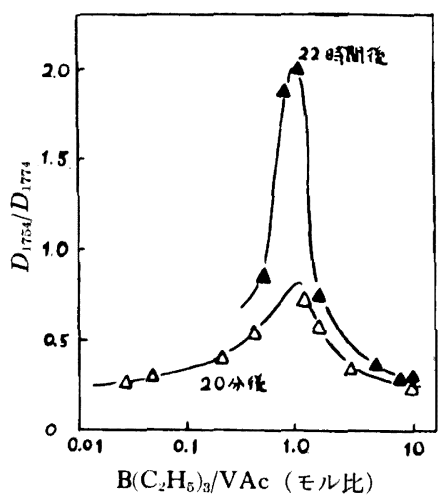

第 2 図 VAc のーキサン溶液に $\mathrm{B}\left(\mathrm{C}_{2} \mathrm{H}_{5}\right)_{8}$ 添加をし た場合の $\mathrm{B}\left(\mathrm{C}_{2} \mathrm{H}_{5}\right)_{8}$ 量と吸収の移動の関保 $\left(20^{\circ} \mathrm{C}\right)$ 
となることが明らかになった。

反応時間の経過に従い, このスペクトルの変化を観察 すると, $\mathrm{B}\left(\mathrm{C}_{2} \mathrm{H}_{5}\right)_{3}$ 添加後しだいに吸収の分岐が起り，2 時間ぐらいでほぼ一定の值に達するようである(その後 にも若干の変化は起る)。第 2 図は添加後 20 分および 22 時間へて観察された $1774 \mathrm{~cm}^{-1}$ と $1754 \mathrm{~cm}^{-1}$ の吸収の 吸光度の比を $\mathrm{B}\left(\mathrm{C}_{2} \mathrm{H}_{5}\right)_{3}$ の添加量に対してプロットした ものである。以上の結果より VAc と $\mathrm{B}\left(\mathrm{C}_{2} \mathrm{H}_{5}\right)_{8}$ の相互 作用によってこのような吸収の変化が起っているものと 考えられる。この吸収の変化は窒素下で観察したもので あるが，1度分岐を生じた采に空気を接触せしめてもス ペタトルは変化しなかった。二重結合を持た好酢酸エチ ルその他のエステルでは, 吸収の変化は認められなかっ た。

\subsection{VAc-Cd $\left(\mathrm{CH}_{3}\right)_{2}$ 系}

次に $\mathrm{Cd}\left(\mathrm{CH}_{3}\right)_{2}$ 添加の影響在調べた。 $\mathrm{B}\left(\mathrm{C}_{2} \mathrm{H}_{5}\right)_{3}$ の場 合上同様にVAcに対して等モル量の $\mathrm{Cd}\left(\mathrm{CH}_{3}\right)_{2}$ 在添加 して吸収スペクトルの変化を観察した。第 3 図に示すよ うに, $\mathrm{B}\left(\mathrm{C}_{2} \mathrm{H}_{5}\right)_{3}$ の場合と同様に $\mathrm{C}=\mathrm{O}$ の吸収の分岐が認

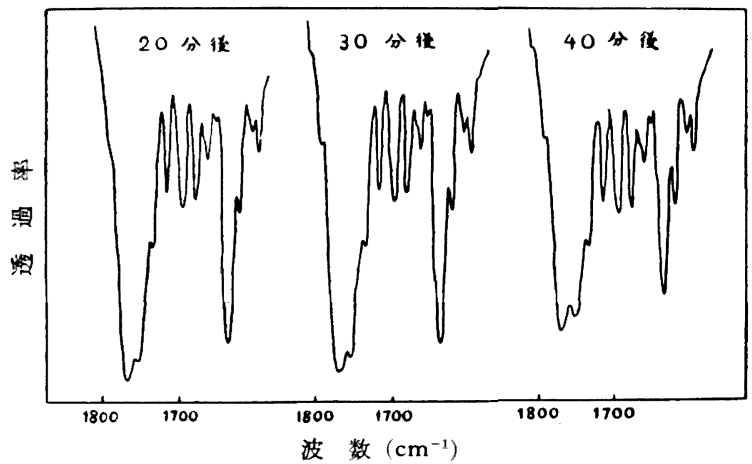

第 3 図 $\mathrm{Cd}\left(\mathrm{CH}_{3}\right)_{2}$ 添加によるVAcのスペクトルの 変化の時間経過

められるが，時間経過とともにVAc の吸收が全体的に 減少していくのが認められた。 $\mathrm{Cd}\left(\mathrm{CH}_{3}\right)_{2}$ 添加とともに 溶液は白濁し，しだいに色沈殿が生成するのが羿めら れるか゚，これは VAc と $\mathrm{Cd}\left(\mathrm{CH}_{3}\right)_{2}$ の相互作用によって 不溶性の沈殿が生成し，そのために吸収が減少していく ことによると考えられる。

次にVAcに対して約 6 倍量の $\mathrm{Cd}\left(\mathrm{CH}_{3}\right)_{2}$ を加えたと ころ, 第 4 図に示すよ5に二重結合の吸収も若干減少し ているが, VAcの $\mathrm{C}=\mathrm{O}$ の特性吸収 $\left(1774 \mathrm{~cm}^{-1}\right)$ は大幅に 減少し, $1750 \mathrm{~cm}^{-1}$ の新しい吸収が增大寸ることが認め られた。この現象は $\mathrm{B}\left(\mathrm{C}_{2} \mathrm{H}_{5}\right)_{3}$ の場合と対照的である。

$\mathrm{Cd}\left(\mathrm{CH}_{3}\right)_{2}$ を酢酸エチルのへキサン溶液に添加して吸 収の変化を調べたところ, VAcの場合と同じよ5に $1750 \mathrm{~cm}^{-1}$ の $\mathrm{C}=\mathrm{O}$ の特性吸收が $1736 \mathrm{~cm}^{-1}$ に分岐を生 ずることが認められたにの場合にも添加後 10〜20 分で

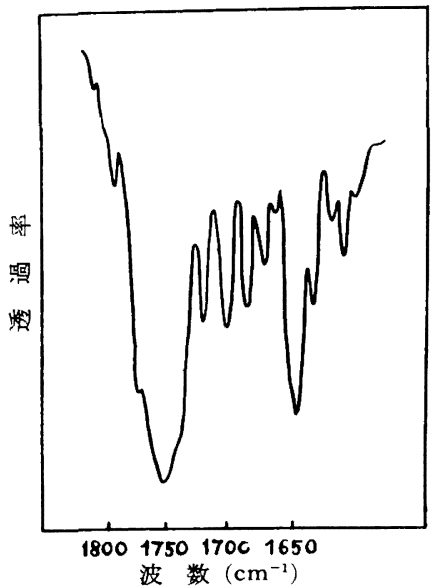

(モル比 VAc: $\mathrm{Cd}\left(\mathrm{CH}_{3}\right)_{2}=1: 6$, 添加後 8 分)

第 4 図過剩の $\mathrm{Cd}\left(\mathrm{CH}_{3}\right)_{2}$ の添加による VAc の スペクトルの変化

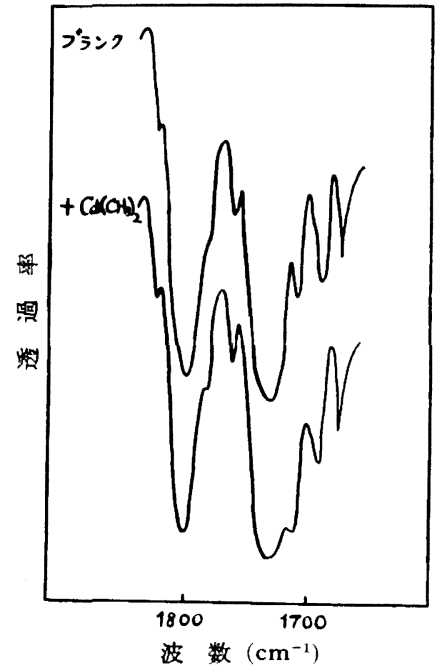

(モル比 VAc unit: $\mathrm{Cd}\left(\mathrm{CH}_{3}\right)_{2}=1: 3$ )

第5 图PVAc のベンゼン溶液の $\mathrm{Cd}\left(\mathrm{CH}_{3}\right)_{2}$ 添加に よるスペクトルの変化

白濁，沈殿生成が認められるが，スペクトルの変化は添 加後ただちに観察される)。

次にPVAc の $5 \%$ ベンゼン溶液に, モル比で約 3 倍 量の $\mathrm{Cd}\left(\mathrm{CH}_{8}\right)_{2}$ を添加してスペクトルの変化を調べた (PVAc の濃度はモノマー単位で計算した)。第 5 図に示 すように, PVAc の C = O の特性吸収が $1722 \mathrm{~cm}^{-1}$ (へ ンゼン中)に分岐を生ずることが羿められた。

\subsection{VAc- $\mathrm{Cd}\left(\mathrm{CH}_{3}\right)_{2}$ 不応生成物について}

VAc と $\mathrm{Cd}\left(\mathrm{CH}_{3}\right)_{2}$ より生成した白色沈殿を口別し， ヘキサンで数回洗浄後乾燥して単離した。この物質は 


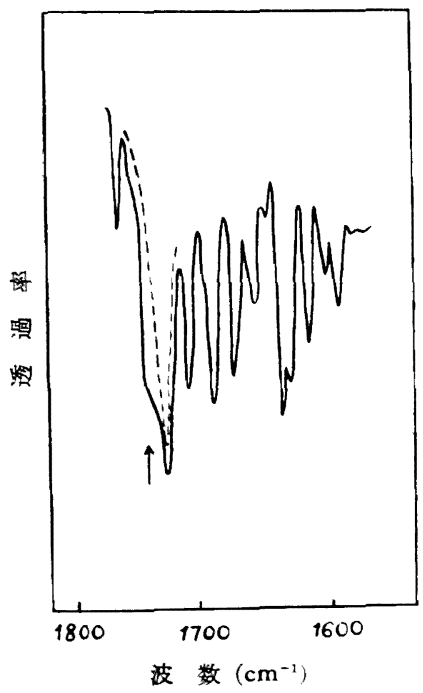

(点線は nujol のみの場合の吸収を示す)

第 6 図 VAc- $\mathrm{Cd}\left(\mathrm{CH}_{3}\right)_{2}$ 反応生成物の赤外吸収 スペクトル (nujol 法)

VAcにほとんど容けないが弱以重合触媒能を示す吸湿 性の粉末である。この粉末 $10 \sim 20 \mathrm{mg}$ 立流動パラフィ ンで練り合わせ，吸収スぺクトルを観察した。第6図に 示すよ $5 に C=0$ の吸収は分岐した位置に相当すると認 められる。次にこの白色沈殿物につ、てア七チル基㧍よ び二重結合の定量を行なった。第 1 表に Kögel 法 $^{3)}$ に よるアセチル基の定量結果を示す。

第 1 表 Kögel 法による白色沈殿の アセチル基定量結果

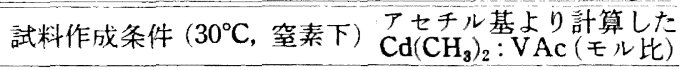

ヘキサン中, 2 日間放置 $1: 0.936$

VAc : $\mathrm{Cd}\left(\mathrm{CH}_{3}\right)_{2}=2: 1$

ヘキサン中, 5 時間放置

$1: 0.898$

VAc : $\mathrm{Cd}\left(\mathrm{CH}_{3}\right)_{2}=1: 1$

石油エーテル中, 20日間放置

$1: 0.473$

VAc : $\mathrm{Cd}\left(\mathrm{CH}_{3}\right)_{2}=1: 1$

へキサン中, 2 日間放置

$1: 0.838$

VAc : $\mathrm{Cd}\left(\mathrm{CH}_{3}\right)_{2}=1: 2$

種々の条件下で得られた沈殿物の組成は、、れずも $\mathrm{Cd}\left(\mathrm{CH}_{3}\right)_{2}: \mathrm{VAc}=1: 1$ に近い值である。ただ 20 日間放 置した場合の值だけは, 他と比べてアセチル基含量が低 いことを示している。またこの沈殿は, 酢酸と激しく反 応しながら溶解するので, 酢酸酸性のメタノールに溶解 せしめ臭素付加による二重結合の定量を試みたが，いず れの場合にも二重結合の存在は認められなかった。

以上の実験結果から, VAc と $\mathrm{Cd}\left(\mathrm{CH}_{3}\right)_{2}$ の間の反応で
は, VAc の C=0 の位置に付加が起っていると考えら れる。一般にカドミウムアルキル $\left(\mathrm{CdR}_{2}\right)$ は, その反応性 が弱いことを利用してケトン合成に使用されるのである が，特に反応性に富むケトンないしはェステルは $\mathrm{CdR}_{2}$ と反応する゙。VAcと $\mathrm{Cd}\left(\mathrm{CH}_{3}\right)_{2}$ が $\mathrm{C}=\mathrm{O}$ の位置で反応 したとすれば，通常の有機金属化合物の付加之同様に考 えて次のような型に付加するであろう。

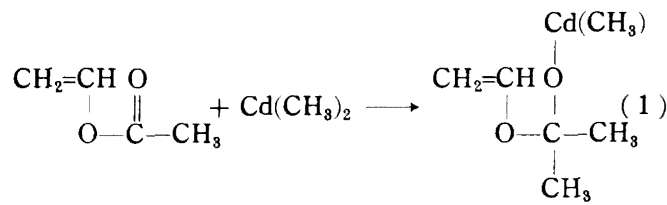

そして付加生成物 (1) はアセトンを脱離し, 加水分解を受 けてナルデヒドとカドミゥム化合物になると予測される が，付加および分解が実際にこのように起るかどらかは 生成物を正確に分析していなので，このような付加を考 えるのは今の段階では危険であるが、これを裹ゔける事 実上して，これらの反応の結果生じるア七トンやアルデ ヒドがポリマー末端に導入されることが留められた。 PVAc をケン化して得られるポリビニルアルコールのカ ルボニル基量の定量結果は $\mathrm{B}\left(\mathrm{C}_{2} \mathrm{H}_{5}\right)_{8}$ と $\mathrm{Cd}\left(\mathrm{CH}_{3}\right)_{2}$ の間 に差が存在することを示している。重合条件によるこれ らカルボニル基量の変化については別の機会に報告する 子定である。したがって実験事実としていい5ることは, $\mathrm{VAc}$ と $\mathrm{Cd}\left(\mathrm{CH}_{3}\right)_{2}$ より生ずる白色沈殿は両者 1:1の化合 物で臭素付加能力はないという事実である。PVAc や他 のエステルと $\mathrm{Cd}\left(\mathrm{CH}_{8}\right)_{2}$ が反応する事実からも $\mathrm{C}=\mathrm{O}$ の 位㯰への付加が起ると考えられるが，二重結合に対する 付加の可能性についてはなお検討の余地があろら。また 実際に取り出した白色沈殿が反応のどの段階のものか, 単一の物質から成るものかなどについて，すべて明らか にされたわけではないが VAc と $\mathrm{Cd}\left(\mathrm{CH}_{3}\right)_{2}$ の $1: 1$ の 付加生成物ないしはその分解生成物との混合物とするの が妥当と考える。 $\mathrm{Cd}\left(\mathrm{CH}_{3}\right)_{2}$ に比して $\mathrm{Cd}\left(\mathrm{C}_{2} \mathrm{H}_{5}\right)_{2}$ の方が より反応性に富むようであり， $\mathrm{CdR}_{2}$ のアルキル基によ り付加の起りやすさが異なることも注目される。

先に PVAc と $\mathrm{Cd}\left(\mathrm{CH}_{3}\right)_{2}$ との反応をスペクトル的に 観察したが, PVAc のベンゼン溶液に $\mathrm{Cd}\left(\mathrm{CH}_{3}\right)_{2}$ を添加 して放置するとゲル化が起ることが認められた。アルミ ニウムおよぴ車鉛のアルキル化合物の添加もカドミウム の場合とよく似た反応が起ることが認められ，またVAc への添加も着色や沈殿生成が観察されることからも $\mathrm{C}=\mathrm{O}$ 基に対して $\mathrm{CdR}_{2}$ と類似の反応性を持つと考えられる。 ただ赤外線吸収スペクトルの観察はセルが污損されるお それがあるために十分行なえなかった。 $\mathrm{B}\left(\mathrm{C}_{2} \mathrm{H}_{5}\right)_{3}$ の場 合に生じる $\mathrm{C}=\mathrm{O}$ の吸収の移動は，なにによるものか不 明であるが, $\mathrm{B}\left(\mathrm{C}_{2} \mathrm{H}_{5}\right)_{3}$ が他のカドミウム, アルミニウ 
ム, 覀鉛のアルキル化合物と比べて VAc に対して反忘

性を異にすることは明らかである。これらの差異が重合 反応にどのように影響するか，今後検討を進めたいと思 5。

付 記：発表を整可された会社当局に感謝する。なお本 報告は高分子研究発表会 (昭和 33 年 11 月 京都)において発表 した。

文献

1）たとえば, 古川ら：工化, 61, 723(1958)

2）たとえば，芦刚：J. Polym. Sci., 28, 250(1958)

3) 船久保：有機化合物確認法(上), 92ページ

4) G.E. Coates: "Organo-metallic Compound", 43 (Methuen \& Co., 1956)

\title{
Polymerization of Vinyl Acetate by Metal Alkyls
}

\section{The Infrared Spectra of Vinyl Acetate-Metal} Alkyl Reaction Mixtures

\author{
By Kiyoshi Fujii*, Tamotsu Eguchi*, Yujiro Kazusa*, \\ Junji Ukida* and Masakazu Matsumoto*
}

\begin{abstract}
Changes in the infrared spectrum of vinyl acetate by the addition of some metal alkyls were observed. On the addition of triethyl boron to $5 \%$ solution of vinyl acetate in hexane, the carbonyl absorption band of vinyl acetate splits into two bands which adsorb at $1754 \mathrm{~cm}^{-1}$ and $1774 \mathrm{~cm}^{-1}$ respectively. The ratio of optical densities of these bands reaches its maximum value when the molar ratio between triethyl boron and vinyl acetate is nearly $1: 1$. When dimethyl cadmium was added, the gradual decrease of total absorption bands as well as the split of the carbonyl band was observed. And the larger amount of dimethyl cadmium was added, the more split was observed. This is probably due to the interaction of carbonyl groups and dimethyl cadmium, and 1:1 adduct of vinyl acetate and dimethyl cadmium was isolated and confirmed by analysis. Dimethyl cadmium was also proved to attack the $\mathrm{C}=\mathrm{O}$ groups of polyvinyl acetate. In the case of triethyl boron, the reason of split occurrence is not known so far, but it is clear that its behaviour markedly differs from that of dimethyl cadmium. It seems likely that zinc and aluminum alkyls behave similarly as cadmium alkyls.
\end{abstract}

* Research Laboratory Kurashiki Rayon Co. Ltd. (Sakazu, Kurashiki, Okayama) 